\title{
Impact of Employee Motivation on Customer Satisfaction: Study of Airline Industry in Pakistan
}

\section{Shahzad N*}

Pakistan Army Aviation, Riphah International University, Islamabad, Pakistan

\begin{abstract}
In success or failure of any firm/industry or organization employees plays the most vital and important role. Airline industry is one of service industry the job of which is to sell seats to their travelers/costumers and passengers; hence employees inspiration towards their work plays a vital part in serving client's requirements. This research focused on the influence of employee's enthusiasm and its apparatuses e.g. pay and benefits, working atmosphere, vision of organization towards customer satisfaction and management systems in Pakistani airline industry. For analysis correlation and regression methods were used. Results of the research highlighted that workers motivation and its four major components e.g. pay and benefits, working atmosphere, vision of organization and management systems have a significant positive impact on customer's gratification. Those employees of the industry who directly interact with client highly impact the client satisfaction level. It is obvious from results of this research that pay and benefits performs a key role in employee's motivation towards achieving their organizational objectives of greater customer satisfaction.
\end{abstract}

Keywords: Customer satisfaction; Employee motivation; Working atmosphere; Pay and benefits; Organizational vision and management systems

\section{Introduction}

Employees perform an important part in determining the customer's perception which they carry in their thoughts in relation to any organization/company through their behavior and actions. Companies spend huge money for creating loyalty of their customer but normally overlook the serious aspect of increasing employee's motivation for achieving their economic and nonfinancial objectives. Keeping in view the today's extreme competition atmosphere in which companies/organizations are operating, employees can perform a vital role in achieving customers' minds, thoughts and hearts. Due to globalization, competition among companies has increased tremendously as companies/organizations are now exposed to competition with other corporations not only inside country but also in competition globally. Organizations are spending heavy amount in gaining advanced technology, development of new procedures/ processes, and in introduction of new products with aim of serving their customers. Organizations have hired professional consultants and also have set up new departments for development of new strategies to compete global market effectively. Every day costumers find new better and more attractive promotional schemes offered by companies to get a lead in competing world. Simultaneously numerous organizations pay attention on their staffs for gaining competitive edge. Technology, organizational structure, procedures and processes of other successful companies can be copied but at the same time employees' dedication and motivation which make that company successful cannot be taken away easily.

These evidences highlight that employees motivation is an important factor in developing customers satisfaction. Personal characteristics and work place atmosphere both affect employees' motivation. Employees' motivation benefits in numerous ways to any organization. Two-way communications always assists in shaping employees perception and at the same time also help companies in understanding their employees need. In service industry employee satisfaction have a positive impact on customer gratifications/satisfaction [1]. Clients are more influenced by employee's behavior once they interact with client rather than companies marketing campaigns or building brand impression. In marketing one of the vital concepts is customer gratification which is not only vital factor theoretically but is also vital factor practically. They highlighted that as compared to manufacturing industry in service industry obtaining customer satisfaction is a difficult task because of direct employee interaction with customers which usually result in intangibility and inconsistency of services [2]. They also indicated that employee enthusiasm is important factor of quality service which effects customer satisfaction. Millions of passengers have travelled around the globe in $21^{\text {st }}$ century using thousands of aircrafts. Worldwide hundreds of airlines are functioning for transportation of passengers globally and also in return earning profits. Aviation industry has assisted in economic development, international tourism/trade as well as in building international relations. In brief, aviation industry has a major contribution towards globalization. Keeping in view rise in fuel prices, global economic crisis and emerging security threats, airline industry cost has raised manifolds. Recently these factors have resulted in huge financial losses by numerous airlines. Therefore, customer satisfaction has emerged as major competitive edge for aviation industry. This research has made an attempt to discover employee motivation and its component's impact on customer satisfaction in Pakistan's airline industry.

\section{Literature Review}

In competing business atmosphere, companies carry out market surveys to examine costumer's preferences. They highlighted that to determine customer's priorities in routine market surveys is carried out by companies $[3,4]$, discovered that in today's competing business

*Corresponding author: Shahzad Naeem, Pakistan Army Aviation, Riphah International University, Islamabad, Pakistan, Tel: +923335491914; E-mail: shahzadflyer@yahoo.com

Received March 26, 2018; Accepted April 11, 2018; Published April 16, 2018

Citation: Shahzad N (2018) Impact of Employee Motivation on Customer Satisfaction: Study of Airline Industry in Pakistan. J Foren Psy 3: 138. doi: 10.4172/2475-319X.1000138

Copyright: (C) 2018 Shahzad N. This is an open-access article distributed under the terms of the Creative Commons Attribution License, which permits unrestricted use, distribution, and reproduction in any medium, provided the original author and source are credited. 
world, organizations monitor customer satisfaction level for continuous improvement in service quality. He indicated that better customer satisfaction leads towards customer's loyalty [5]. Employees must be professionally sound and should have required information and skills while replying customer questions. By ensuring this employees can assist in building customer satisfaction towards their service. Service outcomes are evaluated by customers on basis of preceding expectations and delivered service/product. Basing upon comparison between customer's expectations and real service provided, service results can be positive or negative.

Customer's perceived expectation is a major factor which effects customer satisfaction [5], numerous companies while carrying out customer satisfaction assessments usually neglects evaluation of level of employee's motivation. Though many researches have confirmed that employee's satisfaction contribute towards overall satisfaction of customers as well as performance of organization [6]. In any service industry/sector, exceptional service quality plays a vital role in customer satisfaction, while motivated staffs are necessary for improvement of quality of service [6]. Employees should have the capability to comprehend and resolve exact costumer needs in a polite manner. Motivated workers can produce better outcome in comparison with discontented employees. Employees perform better while performing assigned duties when feel contented from their organizations/ companies $[7,8]$, highlighted that investment by any company in development of enthusiastic employees will benefit the company finally because it enhances service quality as well as employee efficiency.

Cho et al. [9] advised that by minimizing the worker cost may result in lower service quality and worker productivity. Organizations must cultivate promising healthier working atmosphere for achieving enhanced service quality and workers output. Organizations must provide such working atmosphere where workers contribution towards attaining organizational goals and problem solving is valued. He established that organizations can inspire/motivate their workers by giving handsome salaries, growth opportunities and healthier organizational culture. Through motivating workers towards their job companies can increase their worker's productivity which in return will result in better-quality products, services and customer's demand satisfaction [8]. Fulmer et al. [10], highlighted that employees attitude during dealing the customers can influence level of customer's satisfaction positively if employer is able to fulfill customer needs/requirements. Numerous researches have been carried out for identification of employee's influence on customer's opinion/ perception which is likely to build product/service image. Employees who are involved in provision of direct customers' service perform a role of strong medium to build and enhance brand image. Worker motivation towards their work can impact on customer's satisfaction and service quality significantly [11]. Various researches have been conducted for evaluation of employee's influence on performance of company. Repeatedly results have showed that there is a positive connection among employee's attitude and performance of company. Companies which are professed as best in their industry usually pay attention towards employee's attitude motivation by offering them different packages/advantages [8]. In promoting service sector, efficient customer service has performed vital role towards customer satisfaction. In service industry employee motivation importance is much more vital as compared to any other industry because in service industry employees have direct interaction with customers. In the service industry for achieving enhanced level of customer satisfaction and employees productivity mainly employees' motivation and their organizational commitment is vital [1]. Models and theories developed for measuring tangible products are not applicable in service industry.

Oliver [12] highlighted that intangible assets role for example, customer relationships, knowledge, information, systems, etc. It is important for competing in rapid changing financial/economic world. Better customer satisfaction is achieved by companies through keeping their staff happier and motivated, as motivated staff provides better customers services. From results of this research it can be concluded that in any firm's performance improvement, strategic human resources perform a vital role [8]. Employees employed at frontline must have positive customers interaction because it will have a great influence on overall service quality evaluation. It is observed that frontline employee's better interaction can bridge numerous service lapses aspects [13]. In any airline industry staff can influence service quality by their customer's interaction directly or indirectly. Keeping in view nature of service intensity, union representation in airline industry, higher labor cost and relationship among employees and airline is significant. In numerous ways any airline staff can affect airline performance.

Different scholars have assessed service quality of various airlines in diverse categories. Some scholars gathered service quality in airline into four groups (i.e service, price, schedules and choice) while few other researchers gathered them into three groups only (i.e timeliness safety and price). Larrán et al. [14] indicated that South West airline has been able to maintain little employee turnover ratio and increased employee productivity through creating value for money. George et al. [15] highlighted that competition among airlines has increased tremendously due to enhanced customer awareness regarding service quality. Now a day's in extremely competitive global market airlines attract customers by providing better quality services. Hence it is vital for airlines to retain and increase service quality by every passing day. Airlines which provide supportive and learning atmosphere to their employees with lesser conflicts among management and employees are assumed to perform better. In airline industry employee salaries have a close connection with staff productivity which in return leads toward customer satisfaction [9]. Employees can obtain appropriate employment contracts by using collective bargaining method which normally result in overall increased cost base airline structure. In airline industry workers can generate strikes and service interruptions which can impact productivity negatively and also enhance airline costs. Higher salary structure settled by bargaining can influence financial performance as well as airline productivity [9]. In competitive atmosphere for increasing profitability and market share airline are required to introduce new methods for building customer base loyalty [5]. Southwest airline has created value for workers by using cornerstones of worker relations approach "FUN" and "LUV". This demonstrates respect for staff and inspires them to adore their work. Southwest Airlines success is based upon its staffs that provide higher quality services at lesser cost. Southwest generates competitive advantage by value addition through their staff [14]. For assessment of airline service quality using SERVQUAL technique, price is vital factor during evaluation [15]. Nevertheless quickly airlines recognized that in longer run, price warfare will bring them at no win situation. Mainly this is because airlines are sensitive regarding competitor's rate changes. Consequently, for airlines customer satisfaction has emerged as foremost competitive advantages.

\section{Theoretical Framework}

Theoretical framework of employee motivation has been clearly explained using the four major streams of work environment, pay 
and benefits, management systems and organizational vision to reach customer satisfaction (Figure 1).

\section{Research Hypothesis}

- H 1: Employee motivation has positive influence on customer satisfaction.

- H 2: Work environment has positive influence on customer satisfaction.

- H 3: Pay and benefits have positive influence on customer satisfaction

- H 4: Management systems have positive influence on customer satisfaction.

- H 5: Organizational Vision has positive influence on customer satisfaction

\section{Methodology}

\section{Sample and instruments}

In this research employee in Pakistani airline industry motivation along with its four factors impact on customer satisfaction has been analyzed. To measure employee motivation questionnaire of Ahmad, et al. [6], was primarily used and the same was modified where required whereas questionnaire regarding customer satisfaction was selfdeveloped. Data was collected from leading Pakistani private airline.

Data was collected in two phases. Firstly data was collected from those employees who have direct contact with customers like services handling passenger and flight attendants. Keeping employee direct influences on customer satisfaction employees were selected. In flight services to passenger are provided by flight attendants while employees providing passenger handling services assist customers on airports during arrival and departure. To maintain anonymity researcher directly collected questionnaires. Three hundred questionnaires were filled by

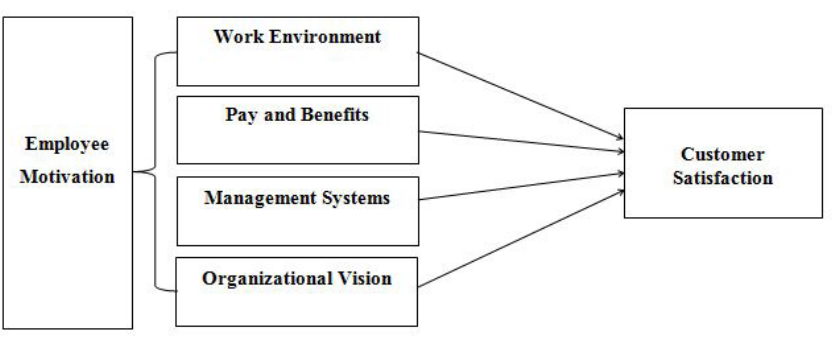

Figure 1: Theoretical framework of employee motivation

\begin{tabular}{|c|c|c|c|c|c|c|c|}
\hline \multicolumn{4}{|c|}{ Employee's Demographics } & \multicolumn{4}{|c|}{ Customer's Demographics } \\
\hline Items & Cat & No & Age (\%) & Items & Cat & No & Age (\%) \\
\hline \multirow{2}{*}{ Gender } & Male & 45 & $15 \%$ & \multirow{2}{*}{ Gender } & Male & 132 & $66 \%$ \\
\hline & Female & 255 & $85 \%$ & & Female & 68 & $34 \%$ \\
\hline \multirow{2}{*}{ Age } & 20-32 & 276 & $92 \%$ & \multirow{3}{*}{ Age } & $20-32$ & 98 & $49 \%$ \\
\hline & $33-46$ & 24 & $8 \%$ & & $33-46$ & 84 & $42 \%$ \\
\hline \multirow{3}{*}{ Education } & Intermediate & 60 & $20 \%$ & & $47-60$ & 18 & $9 \%$ \\
\hline & Bachelors & 141 & $47 \%$ & \multirow{4}{*}{$\begin{array}{l}\text { Traveler } \\
\text { Type }\end{array}$} & $\begin{array}{l}\text { Frequent } \\
\text { Flyer }\end{array}$ & 106 & $53 \%$ \\
\hline & Masters & 99 & $33 \%$ & & Limited & 94 & $47 \%$ \\
\hline \multirow{2}{*}{$\begin{array}{l}\text { Years of } \\
\text { Service }\end{array}$} & $1-10$ & 279 & $93 \%$ & & Economy & 200 & $100 \%$ \\
\hline & $11-20$ & 21 & $7 \%$ & & Business & 0 & $0 \%$ \\
\hline
\end{tabular}

Table 1: Demographic characteristics of respondents. airline employees. In second phase questionnaire were distributed to airline customers. Customers were selected randomly and two hundred questionnaires were filled (Table 1).

\section{Methods}

For analyzing questionnaire data SPSS version 17 statistical package was used. In first step, Cronbach's alpha was used to test the validity and reliability of questionnaire regarding customer satisfaction and employee motivation. Later, for testing relationship between employee motivation (IV) and customer satisfaction (DV) Pearson correlation and regression analysis was used. The same method was repeated for testing impact of four employee motivation components i.e. management system, pay and benefit, organizational vision and work environment (IV) on customer satisfaction (DV).

\section{Results and Discussions}

The employee motivation questionnaire consists of 23 items for and customer satisfaction questionnaire consists of 24 items. Results highlight that employee motivation Cronbach's alpha is 0.726 and customer satisfaction is 0.750 which was within acceptable range of reliability. Detailed results were given in Table 2.

Table 3 shows correlation analysis results which established the relationship among variables. Correlation results highlighted that employee motivation was 0.703 correlations at significant level of $<1 \%$ with customer satisfaction which mean $70.3 \%$ correlation with each other. Analysis by component wise indicates that all components i.e. pay and benefit, work environment, organizational vision and management system have positive significant relation with correlation $0.333,0.591$, 0.481 and 0.472 correspondingly at a significant level of $<1 \%$.

Table 4 indicates model summary results and also evaluates fitness of the model, highlighted that $\mathrm{R}$ square higher value indicates the strength of model. Research results indicate $\mathrm{R}$ squared is 0.494 which means $49.4 \%$ of model has been described [16]. Value of adjusted $\mathrm{R}$

\begin{tabular}{|c|c|c|}
\hline Measures & Items & Cronbach's Alpha \\
\hline Employee Motivation & 23 & 0.726 \\
\hline Customer Satisfaction & 24 & 0.75 \\
\hline
\end{tabular}

Table 2: Results of validity and reliability analysis.

\begin{tabular}{|l|l|l|l|l|l|l|l|}
\hline SI.no & $\begin{array}{l}\text { Pearson } \\
\text { Correlation }\end{array}$ & $\mathbf{1}$ & $\mathbf{2}$ & $\mathbf{3}$ & $\mathbf{4}$ & $\mathbf{5}$ & $\mathbf{6}$ \\
\hline 1 & $\begin{array}{l}\text { Customer } \\
\text { Satisfaction }\end{array}$ & 1 & - & - & - & - & - \\
\hline 2 & $\begin{array}{l}\text { Employee } \\
\text { Motivation }\end{array}$ & $0.703^{* *}$ & 1 & - & - & - & - \\
\hline 3 & $\begin{array}{l}\text { Work } \\
\text { Environment }\end{array}$ & $0.333^{* *}$ & $0.491^{* *}$ & 1 & - & - & - \\
\hline 4 & \begin{tabular}{l} 
Pay and Benefit \\
\hline 5
\end{tabular} & $0.591^{* *}$ & $0.900^{* *}$ & $0.275^{* *}$ & 1 & - & - \\
\hline $\begin{array}{l}\text { Management } \\
\text { System }\end{array}$ & $0.481^{* *}$ & $0.705^{* *}$ & -0.032 & $0.624^{* *}$ & 1 & - \\
\hline 6 & $\begin{array}{l}\text { Organizational } \\
\text { Vision }\end{array}$ & $0.472^{* *}$ & $0.426^{* *}$ & 0.109 & $0.334^{* *}$ & $0.333^{* *}$ & 1 \\
\hline *Means significant at <1\% level. & & & & & \\
\hline
\end{tabular}

Table 3: Correlation between variables and descriptive statistics.

\begin{tabular}{|l|l|l|l|l|l|}
\hline Model & $\mathbf{R}$ & $\begin{array}{l}\mathbf{R} \\
\text { Square }\end{array}$ & $\begin{array}{l}\text { Adjusted R } \\
\text { Square }\end{array}$ & $\begin{array}{l}\text { Std. Error of the } \\
\text { Estimate }\end{array}$ & $\begin{array}{l}\text { Durbin- } \\
\text { Watson }\end{array}$ \\
\hline 1 & 0.703 & 0.494 & 0.489 & 0.99923 & 0.235 \\
\hline a. Predictors Constant: Employee Motivation. \\
b. Dependent Variable: Customer Satisfaction.
\end{tabular}

Table 4: Results of model summary. 
squared is 0.489 which is closer to $\mathrm{R}$ square value. Predictability level is low but as we know numerous other variables also effect customer satisfaction. But, in this research analysis employee motivation is taken into consideration. Therefore the indicated predictability level is sufficient. To check problem of auto correlation in data applied DurbinWatson test was run [16] described that if Durbin-Watson is closer to 2 , it means that in used data there is no auto-correlation. In this research Durbin-Watson value is 2.035 which is closer to 2 and also confirms that there in used data there is no auto correlation.

That the model which has large regression sum of squares as compare to residual sum of squares indicates that most of variation in dependent variable (DV) is considered in model ANOVA results are showed in Table 5 [16]. When significant value of $F$ statistic is lesser than 0.05 then independent variables (IVs) describes dependent variables (DVs) in excellent manner. Results of this research indicates that regression sum of squares is just under the residual sum of squares in employee motivation. In analysis the main hypothesis concerning customer satisfaction and employee motivation has $96.214 \mathrm{~F}$ value at significant level which is lesser than $1 \%$. This confirms that model is fit for use.

The Table 6 shows regression analysis results. Results indicate that $\mathrm{t}$-value $=9.808$ at significant level of lesser than $1 \%$. Hence, hypothesis $\mathrm{H} 1$ is accepted and it can be concluded that in Pakistani airline industry employee motivation has a significant positive impact on customer satisfaction. Results of this research are similar to $[8,11]$ that

\begin{tabular}{|c|c|c|c|c|c|c|}
\hline Model & & $\begin{array}{l}\text { Sum of } \\
\text { Squares }\end{array}$ & df & $\begin{array}{l}\text { Mean } \\
\text { Square }\end{array}$ & F. & Sig \\
\hline \multirow{3}{*}{1} & Regression & 96.067 & 1 & 96.067 & 96.214 & $0.000^{a}$ \\
\hline & Residual & 97.849 & 298 & 0.997 & - & - \\
\hline & Total & 193.918 & 199 & - & - & - \\
\hline
\end{tabular}

Table 5: Results of ANOVA

\begin{tabular}{|l|l|l|l|l|l|l|l|}
\hline \multicolumn{2}{|c|}{} & \multicolumn{3}{|l|}{$\begin{array}{l}\text { Un-standardized } \\
\text { Coefficients }\end{array}$} & \multicolumn{2}{l|}{$\begin{array}{l}\text { Standardized } \\
\text { Coefficients }\end{array}$} \\
\hline \multirow{2}{*}{ Model } & & B & Std Error & Beta & t & Sig \\
\hline \multirow{2}{*}{1} & (Constant) & 3.665 & 0.789 & & 4.637 & 0 \\
\cline { 2 - 8 } & Employee Motivation & 2.239 & 0.227 & 0.704 & 9.808 & 0 \\
\hline
\end{tabular}

a. Dependent Variable: Customer Satisfaction

Table 6: Results of regression analysis (Coefficients).

\begin{tabular}{|l|c|c|c|c|c|}
\hline Model & $\mathbf{R}$ & $\mathbf{R}$ Square & $\begin{array}{c}\text { Adjusted R } \\
\text { Square }\end{array}$ & $\begin{array}{c}\text { Std. Error of } \\
\text { the Estimate }\end{array}$ & $\begin{array}{c}\text { Durbin- } \\
\text { Watson }\end{array}$ \\
\hline 1 & $0.697 a$ & 0.487 & 0.465 & 1.02247 & 2.15 \\
\hline $\begin{array}{l}\text { a. Predictors: (Constant), Organizational Vision, Work Environment, } \\
\text { Management System, Pay and Benefit } \\
\text { b. Dependent Variable: Customer Satisfaction }\end{array}$ \\
\hline
\end{tabular}

Table 7: Component wise results of model summary.

\begin{tabular}{|c|c|c|c|c|c|c|}
\hline \multirow{2}{*}{ Model } & & $\begin{array}{c}\text { Sum of } \\
\text { Squares }\end{array}$ & df & $\begin{array}{c}\text { Mean } \\
\text { Square }\end{array}$ & F & Sig \\
\hline \multirow{3}{*}{1} & Regression & 94.597 & 4 & 23.649 & 22.62 & $0.000 a$ \\
\cline { 2 - 7 } & Residual & 99.319 & 94 & 1.044 & - & - \\
\cline { 2 - 7 } & Total & 193.916 & 98 & - & - & - \\
\hline
\end{tabular}

a. Predictors: (Constant), Organizational Vision, Work Environment, Management System, Pay and Benefit

b. Dependent Variable: Customer Satisfaction

Table 8: Component wise results of ANOVA.

\begin{tabular}{|l|l|c|c|c|c|c|}
\hline \multicolumn{2}{|c|}{} & $\begin{array}{c}\text { Un-standardized } \\
\text { Coefficients }\end{array}$ & \multicolumn{3}{|c|}{$\begin{array}{c}\text { Standardized } \\
\text { Coefficients }\end{array}$} \\
\hline & B & Std Error & Beta & t & Sig \\
\hline 1 & 3.711 & 0.925 & & 4.009 & 0 \\
\hline (Constant) & 0.605 & 0.214 & 0.223 & 2.817 & 0.005 \\
\hline Work Environment & Pay and Benefit & 0.697 & 0.229 & 0.311 & 3.038 & 0.003 \\
\hline $\begin{array}{l}\text { Management } \\
\text { System }\end{array}$ & 0.428 & 0.211 & 0.2 & 2.022 & 0.044 \\
\hline $\begin{array}{l}\text { Organizational } \\
\text { Vision }\end{array}$ & 0.483 & 0.137 & 0.276 & 3.497 & 0.001 \\
\hline
\end{tabular}

a. Dependent Variable: Customer Satisfaction

Table 9: Component wise results of Regression Analysis (Coefficients).

organizations/industries/firms motivate their staffs by offering them both financial and non-financial packages/benefits.

Tables 7-9 indicate component wise coefficients results of this research. Results indicate that work environment has $t$ value $=2.817$ at significance level 0.005 . Thus, hypothesis $\mathrm{H} 2$ is accepted and indicates that in Pakistani airline industry. Work environment has significant positive impact on customer satisfaction. Results of pay and benefits highlight that $t$ value $=3.038$ at significance level 0.003 . Hence, hypothesis $\mathrm{H} 3$ is accepted and indicates that in Pakistani airline industry pay and benefits has significant positive impact on customer satisfaction. These results are similar with the results of [8] also discovered positive influence of pay \& benefit on customer satisfaction.

Results of management systems highlight that $t$ value $=2.022$ at significance level 0.044 Hence, hypothesis $\mathrm{H} 4$ is also accepted and indicates that in Pakistani airline industry management systems have significant positive impact on customer satisfaction. Results showed that organizational vision has $\mathrm{t}$ value $=3.497$ at significance level 0.001 . Thus, hypothesis H5 is accepted and indicates that in Pakistani airline industry organizational vision has significant positive impact on customer satisfaction. Results confirmed that all five hypotheses were accepted which showed that employee motivation along with its four components had a significant positive impact on customer satisfaction (DV).

\section{Limitations and Directions for Future Research Directions}

This research has several limitations which must be given due consideration when interpreting the findings. First due to time constraint data was collected only from private airlines operating in Pakistan, therefore collecting data all airlines operating in country with a larger sample will not only overcome the above mentioned limitation, but will also provide a detailed and comprehensive picture. The second limitation concerns to data collection mechanism. Since data was collected by using questionnaire method only. Therefore, it is recommended that for future research, data should be collected by using multiple methods. The third limitation of the study is that due to time constraint, cross sectional data was collected using convenience sampling method. It is recommended that for future study, data must be collected using time lag. Although, the objectives of this study have been achieved but in future by incorporating more relevant variables related to employee performance and evaluation of the results of employee performance on overall performance of employee and the organization can further elaborate the relationship.

\section{Conclusion}

Results showed that employee motivation along with its four factors i.e. pay and benefit, works environment, organizational vision and 
Citation: Shahzad N (2018) Impact of Employee Motivation on Customer Satisfaction: Study of Airline Industry in Pakistan. J Foren Psy 3: 138. doi: 10.4172/2475-319X.1000138

Page 5 of 5

management system has vital contribution in customer's satisfaction of airline industry. Hence, employee motivation can be used for gaining customer satisfaction. Employees who directly interact with customers have high impact on customer satisfaction. Customers assess services of any airline by performance, behavior and attitude of airline employees. From results of research it is evident that pay \& benefits perform a vital role in inspiring employees towards achieving organizational goal of greater customer satisfaction/gratification. While planning and during introduction of new services, airline management must keep in mind factors effecting employees motivation. Service managers must adopt all ways and methods to keep employees motivation level high for ensuring them to provide the assured and promised services. This research work has highlighted that there is need to introduce motivational programs for employee with an aim to improve motivational level of employees for achieving their organizational objectives. This research has investigated and assessed contribution of employees towards services success offered by Pakistani airline industry. Research results provide a clear and better understanding to services management for evaluation of employees' motivation level which in result can assist in improving satisfaction level of their customers. This research has analyzed the influence of employee's motivation level as complete as well as different components of employee's motivation in relationship to satisfaction level of customers Results of this research also offer awareness towards employee's involvement and interest towards their work which can be aligned with organizational goals/objectives for improvement in customer's base satisfaction.

\section{References}

1. Macey WH, Schneider B (2008) The meaning of employee engagement. Industrial and organizational Psychology 1: 3-30.

2. De Coverly E, Holme NO, Keller AG, Thompson FHM, Toyoki S (2002) Service recovery in the airline industry: Is it as simple as 'failed, recovered, satisfied? TMR 3: 21-37.
3. Oriola S (2007) Gauging customer satisfaction.

4. Akroush MN, Abu EAA (2012) An empirical investigation of the mediating role of relationship marketing skills on the relationship between customer satisfaction and customer loyalty. IJIMA 7(1): 1-30.

5. Lam SY, Shankar V, Erramilli MK, Murthy B (2004) Customer value, satisfaction, loyalty, and switching costs: An illustration from a business-to-business service context. J Acad Mark Sci 32(3): 293-311.

6. Ahmad MB, Wasay E, Jhandir SU (2012) Impact of employee motivation on customer satisfaction: Study of airline industry in Pakistan. IJCRB 4: 532-539.

7. Tsaur SH, Lin YC (2004) Promoting service quality in tourist hotels: The role of HRM practices and service behavior. Tour Manag 25(4): 471-481.

8. Goenner CF (2008) Investing in fortune's 100 best companies to work for in America. J Econ 34(1): 1-19.

9. Cho S, Woods RH, Jang SS, Erdem M (2006) Measuring the impact of human resource management practices on hospitality firms' performances. Int J Hosp Manag 25(2): 262-277.

10. Fulmer IS, Gerhart B, Betwe KSSE (2003)KK Psychology: Winter 2003; 56, 4; ABI/INFORM Global. Personnel Psychology 56: 965-993.

11. Gittell JH (2006) Relational coordination: Coordinating work through relationships of shared goals, shared knowledge and mutual respect. Relational perspectives in organizational studies: A research companion, Edward Elgar Publishing, UK.

12. Oliver RL (2014) Satisfaction: A behavioral perspective on the consumer Routledge, UK.

13. Antonides G, Verhoef PC, Van Aalst M (2002) Consumer perception and evaluation of waiting time: A field experiment. J Consumer Psychol 12(3): 193-202.

14. Larrán M, Laffarga J, Galindo A, Giner Y, Jiménez SM, et al. (2005) Eficiencia y situación económico-financiera de las Pyme en Andalucía, Spain.

15. George BP, Henthorne TL, Panko TR (2013) ASQual: Measuring tourist perceived service quality in an airport setting. IJBEX 6(5): 526-536.

16. Malik SU (2012) Relationship between corporate governance score and stock prices: Evidence from KSE-30 index companies. IJBSS 3(4): 239-249. 